\title{
Eating what you like induces a stronger decrease of 'wanting' to eat.
}

Citation for published version (APA):

Lemmens, S. G., Schoffelen, P. F., Wouters, L., Born, J. M., Martens, M. J., Rutters, F., \& Westerterp-

Plantenga, M. S. (2009). Eating what you like induces a stronger decrease of 'wanting' to eat. Physiology \& Behavior, 98(3), 318-325. https://doi.org/10.1016/j.physbeh.2009.06.008

Document status and date:

Published: 01/01/2009

DOI:

10.1016/j.physbeh.2009.06.008

Document Version:

Publisher's PDF, also known as Version of record

\section{Document license:}

Taverne

\section{Please check the document version of this publication:}

- A submitted manuscript is the version of the article upon submission and before peer-review. There can be important differences between the submitted version and the official published version of record.

People interested in the research are advised to contact the author for the final version of the publication, or visit the DOI to the publisher's website.

- The final author version and the galley proof are versions of the publication after peer review.

- The final published version features the final layout of the paper including the volume, issue and page numbers.

Link to publication

\footnotetext{
General rights rights.

- You may freely distribute the URL identifying the publication in the public portal. please follow below link for the End User Agreement:

www.umlib.nl/taverne-license

Take down policy

If you believe that this document breaches copyright please contact us at:

repository@maastrichtuniversity.nl

providing details and we will investigate your claim.
}

Copyright and moral rights for the publications made accessible in the public portal are retained by the authors and/or other copyright owners and it is a condition of accessing publications that users recognise and abide by the legal requirements associated with these

- Users may download and print one copy of any publication from the public portal for the purpose of private study or research.

- You may not further distribute the material or use it for any profit-making activity or commercial gain

If the publication is distributed under the terms of Article $25 \mathrm{fa}$ of the Dutch Copyright Act, indicated by the "Taverne" license above, 


\title{
Eating what you like induces a stronger decrease of 'wanting' to eat
}

\author{
Sofie G.T. Lemmens a,b,*, Paul F.M. Schoffelen ${ }^{a}$, Loek Wouters ${ }^{a}$, Jurriaan M. Born ${ }^{\text {a,b }}$, Mieke J.I. Martens ${ }^{\text {a }}$, \\ Femke Rutters ${ }^{a}$, Margriet S. Westerterp-Plantenga ${ }^{\text {a,b }}$ \\ a Department of Human Biology, Maastricht University, P.O. Box 616, 6200 MD, Maastricht, The Netherlands \\ ${ }^{\mathrm{b}}$ Top Institute Food and Nutrition, P.O. Box 557, 6700 AN Wageningen, The Netherlands
}

\section{A R T I C L E I N F O}

\section{Article history:}

Received 20 March 2009

Received in revised form 15 May 2009

Accepted 11 June 2009

\section{Keywords:}

Reward

'Liking'

'Wanting'

Validation

Computer test

Human

Food

Obesity

\begin{abstract}
A B S T R A C T
Human eating behavior may be influenced non-homeostatically by the rewarding value of foods, i.e. 'liking' (pleasure/palatability) and 'wanting' (incentive motivation). The objectives of this study were to validate a computer test for assessment of rewarding value of food, and to assess how rewarding value of food is affected by eating a dessert-specific (chocolate mousse, CM) vs. dessert non-specific, neutral food item (cottage cheese, CC). Seventy-three subjects (47f $/ 26 \mathrm{~m}$, age $27.8 \pm 10.0 \mathrm{y}$, BMI $24.1 \pm 3.3 \mathrm{~kg} / \mathrm{m}^{2}$ ), studied in a randomized cross-over design, came to the university twice, fasted. A computer test was developed to determine rewarding value, i.e. 'liking' and 'wanting', for 72 items divided in six categories (bread, filling, drinks, dessert, sweets, stationery). 'Liking' was measured by indicating relative preference of paired items (within/between categories), 'wanting' by working to earn items to choose from. Subjects completed the computer test before and after consumption of $\mathrm{CM} / \mathrm{CC}$, matched for energy content $(5.6 \mathrm{~kJ} / \mathrm{g})$ and daily energy requirements (10\%). 'Liking' and 'wanting' scores of all fasted subjects on the two test-days showed $62-73 \%$ reproducibility. CM was liked more than CC $(p<0.001)$. Consumption of CM decreased 'wanting' for bread, filling, drinks and dessert $(p<0.03)$. Consumption of CC decreased 'wanting' for bread only $(p<0.05)$. Contrary to CC, CM decreased relative 'liking' for the dessert category $(p<0.001)$. In conclusion, the computer test for measurement of 'liking' and 'wanting' is sufficiently valid. Eating a highly liked food item induces a more distinct decrease in 'wanting' for food items in general and category-specific 'liking', than eating a sufficiently liked neutral food item.
\end{abstract}

(c) 2009 Elsevier Inc. All rights reserved.

\section{Introduction}

Human eating behavior is not solely regulated by homeostatic mechanisms but also by non-homeostatic mechanisms such as the food reward system. Unraveling this reward system may help us understand the factors that influence the excessive food intake associated with obesity [1-3].

According to the incentive salience theory it is hypothesized that the process of reward consists of two components, i.e. 'liking' and 'wanting' [4]. 'Liking' is the hedonic or affective component and refers to the pleasure derived from oro-sensory stimulation of food $[5,6]$. 'Wanting' is the motivational incentive component and refers to appetite or craving or the motivation to obtain food [1,4-7]. Often 'liking' and 'wanting' go hand-in-hand: we want what we like and like what we want [4]. However, humans habitually may select less liked food items, as for example restrained eaters do: they cognitively restrict their food intake to loose weight or to prevent weight gain $[6,8]$. Furthermore, in research on drug addiction a distinction between

\footnotetext{
* Corresponding author. Maastricht University, PO Box 616, 6200 MD Maastricht, The Netherlands. Tel.: +31 433882124; fax: +31 433670976.

E-mail address: s.lemmens@hb.unimaas.nl (S.G.T. Lemmens).
}

the two components of reward was observed: some drug addicts are driven to take drugs without liking their effects [9,10]. Moreover, 'liking' and 'wanting' are thought to be controlled by different brain mechanisms according to the incentive salience model [7]. Mouse models showed that the brain mechanism attributed to 'liking' involves the neurotransmission of mu-opioid in the nucleus accumbens, ventral pallidum, parabrachial nucleus, and nucleus of the solitary tract [1]. The brain mechanism attributed to 'wanting' involves the neurotransmission of dopamine in the prefrontal cortex, amygdala, hypothalamus, and projections from the ventral tegmental area to the nucleus accumbens [1]. Taking the above into account, it is of importance to differentiate between the possible influence of 'liking' and 'wanting' on food intake [11].

Recent human studies have observed and characterized the distinction between 'liking' and 'wanting' [6]. 'Liking' was quantified by either subjective ratings on visual analog scales or objective measures of facial affective expressions $[3,5,12]$. 'Wanting' was quantified by for example the forced choice methodology whereby food items were presented in pairs and responded according to which food item was most wanted at that moment [2,5]. Epstein et al. developed an alternative indirect measure for motivation by assessing the reinforcing value of food using progressive schedules of reinforcement $[3,13]$. The motivation was expressed as the willingness to work for amounts of a food of choice or 
alternate reinforcers such as money or sedentary activities. According to the approach of Epstein et al. the reinforcing value of food is associated with the 'wanting' of food [3].

When current methods for measurements of 'liking' and 'wanting' are applied in humans, culture specific motivation and reinforcement may have to be taken into account. This is especially of importance since distinguishing 'liking' from 'wanting' seems to be present to a different extent among cultures [14]. Therefore, a computer-based method for the assessment of reward, in terms of 'liking' and 'wanting', was developed for this study. This method is presently applied to a Dutch study population and by using the general principles, a broader application will be possible.

Firstly, the validity, i.e. reproducibility and sensitivity, of the developed computer test for assessment of the rewarding value of food was tested. Secondly, it was assessed how the rewarding value of a consumed food item possibly affects the rewarding value of any other food item in general. Unraveling such a relationship may explain the subject's subsequent food choice and consumption.

\section{Methods}

\subsection{Subjects}

Seventy-three Caucasian subjects ( 47 females, 26 males, age $27.8 \pm$ $10.0 \mathrm{y}$ (mean $\pm \mathrm{SD}$, range $18-55 \mathrm{y}$ )) with a BMI of $24.1 \pm 3.3 \mathrm{~kg} / \mathrm{m}^{2}$ (mean $\pm S D$, range $18.9-30.6 \mathrm{~kg} / \mathrm{m}^{2}$ ) participated in this study. They were recruited by advertisements in local newspapers and on notice boards at the university and hospital. The subjects underwent an initial screening including measurement of body weight and height and completion of a questionnaire related to health, use of medication, smoking behavior, alcohol consumption and physical activity. All subjects gave written informed consent by the start of the first test day. The study was approved by the Medical Ethical Committee of the Maastricht University.

\subsection{Study design}

The study was conducted in a randomized cross-over design. All subjects came to the university twice in a fasted state, between 08:00 and 10:00 AM. The test sessions differed only in the presentation of the test meal: either chocolate mousse or cottage cheese.

After arrival at the university, subjects were seated in the laboratory and remained seated throughout the experiment. The test session started by filling out visual analogue scales (VAS) on appetite. Subsequently the researcher gave the instructions on the computer test for measurement of 'liking' and 'wanting'. While completing the test, subjects received further instructions on the computer screen and on a piece of paper. After completing the computer test, subjects had to consume the entire test meal. Immediately post-ingestion subjects filled out the VAS and completed the computer test again.

\subsection{Appetite profile}

One hundred unit VAS ( $\mathrm{mm}$ ) were used to assess the appetite profile. The scales were anchored with 'not at all' at one end and 'extremely' at the other end, and combined with questions on feelings of hunger, thirst, fullness, satiety, desire to eat, and on 'liking', 'wanting', creaminess, and fullness of taste of the test meals. Subjects were instructed to make a single vertical mark at the appropriate point between the two anchors on each scale to indicate their subjective feeling. These VAS were completed in the fasted and satiated state. Moreover, at the end of both test sessions, subjects completed VAS on the absolute 'liking' of all the items used in the computer test.

\section{4. 'Liking' and 'wanting' computer test}

A computer test was developed to measure the rewarding value, i.e. 'liking' and 'wanting', for 72 items divided in six categories (bread, filling, drinks, dessert, sweets, and stationery (non-food alternative as placebo)), 12 items per category (Appendix Table A1). Those five food categories were chosen as they gave the subjects the opportunity to compose a full meal according to their wishes. A usual Dutch breakfast/lunch consists of bread, filling and drinks. Above this, dessert and sweets can be added. Stationery served as non-food alternative (placebo) in this study. Beforehand, during screening, it was checked whether all food items were acceptable for the subjects. The 72 items were presented as photographic stimuli on a computer screen (13 in. Mac Book, Apple, Cupertino, USA). In a sub-study the pleasantness of taste of all the food items while tasting them and the attractiveness of the photographic stimuli were measured by means of VAS.

The computer test contained two parts, a 'liking' and a 'wanting' part. Both the 'liking' and 'wanting' tasks assessed 'liking' respectively 'wanting' for the same food and stationery items. During the 'liking' part, subjects had to indicate their relative preference of paired items within and between the six categories (Fig. 1A, B). Each choice had to be made within four s via a mouse click on the preferred item, which triggered the next pair of items. First, all possible pairs of combinations within each category were presented $(N=6 \times 66)$. The pairs of items were presented in random order, while the categories were presented in the following order: bread, filling, drinks, dessert, sweets and stationery. This resulted in a relative ranking of 'liking' of the items per category. Next, the items from the different categories with the corresponding ranking of 'liking' were presented in pairs, in random order $(N=12 \times 15)$. This resulted in a relative ranking of 'liking' of the categories.

During the 'wanting' part, subjects had to work to earn items by playing memory games (Fig. 1 C, D). For each category of items subjects played a five by five memory game (12 pairs of items). Per memory game the shuffled pairs of items were first presented for $10 \mathrm{~s}$, giving the subjects the opportunity to locate and remember the pairs of matching items. Next the items were turned over and the subjects could start finding the matching pairs by clicking on them using the computer mouse. Matched pairs remained on the screen, while nonmatched pairs were turned over again. Subjects had two min to solve the memory game. Each memory game was followed by the indication of the items subjects wanted to acquire at that moment. The more pairs of items were found in the memory game, the more randomly selected items were offered to choose from afterwards, e.g. if eight pairs of items would be found in the memory game of the sweets category, then eight randomly selected sweets would be offered to choose from. Subjects could choose zero, one or two items per category. They were instructed to choose the items while keeping in mind that all the chosen items would be offered to them and had to be eaten completely. To proceed to the next category subjects had to find at least two pairs of items per memory game. The categories were presented in the following order: bread, filling, drinks, dessert, sweets and stationery. From the drinks category onwards, subjects could press a stop-button to stop the 'wanting' part of the computer test, indicating that they would not want to work for and earn any other items. The chosen items obtained a score equal to the number of pairs of items found in the memory game, representing the motivation or workload for the chosen items (score range 2-12). Items not chosen obtained a score of zero. Per category the sum of the scores of the items was calculated and represented the 'wanting' score for each category. A minimum score of zero and a maximum score of 24 was obtained per category.

During screening, subjects were asked whether they were able to play a memory game. All subjects confirmed their ability, there were no drop-outs. Moreover subjects were asked during screening to 
A

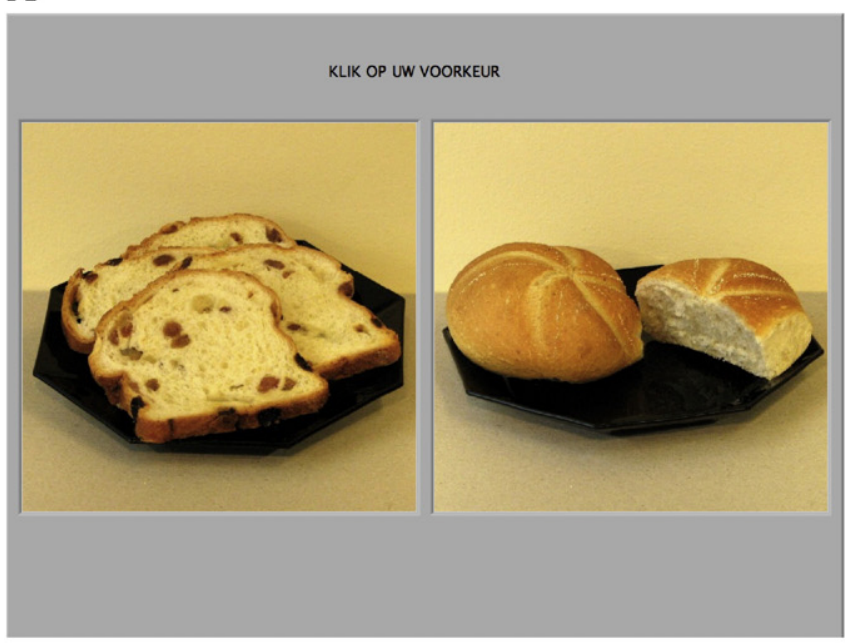

$\mathrm{C}$

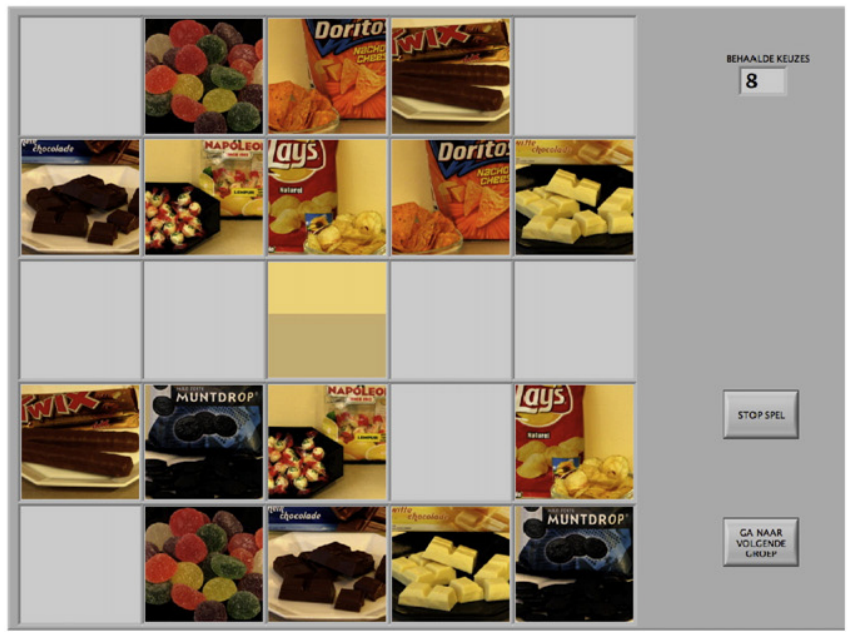

B

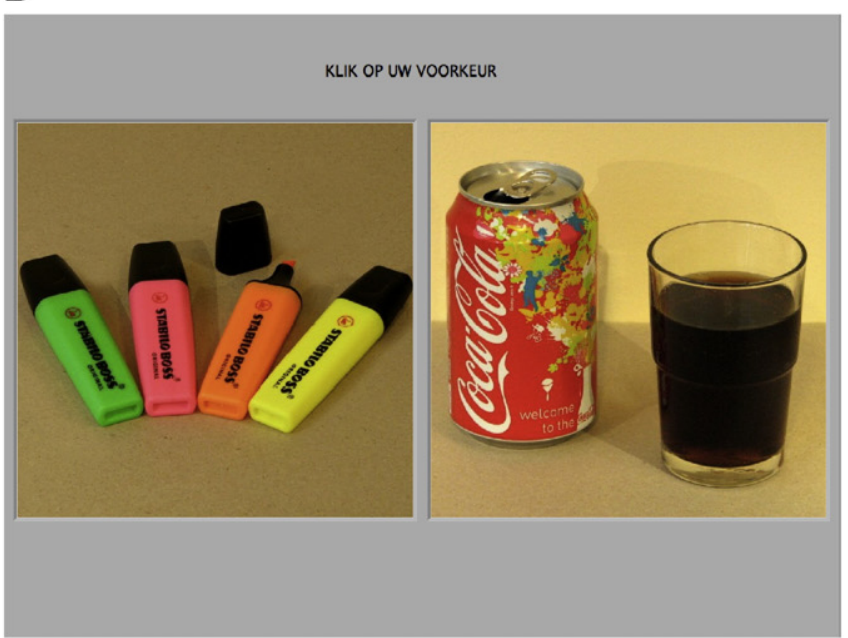

D

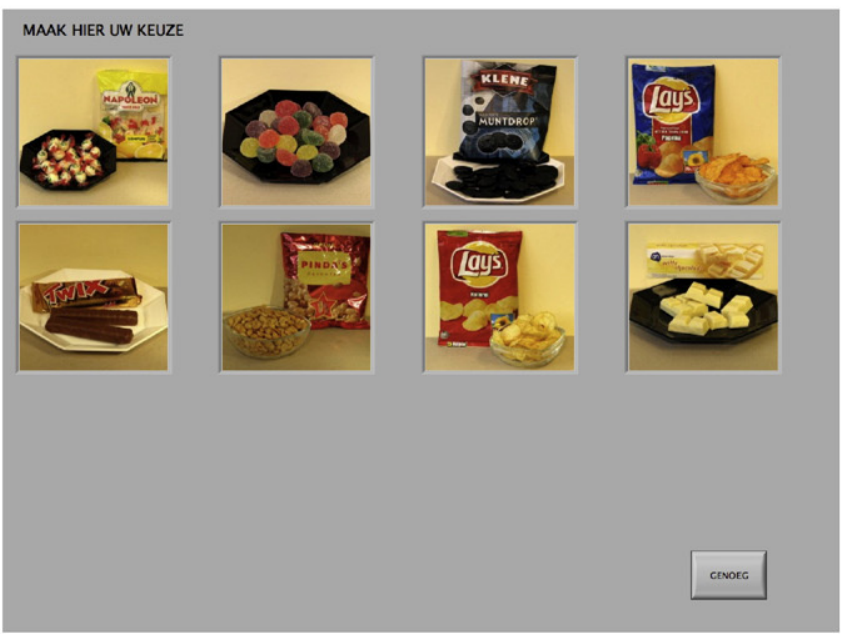

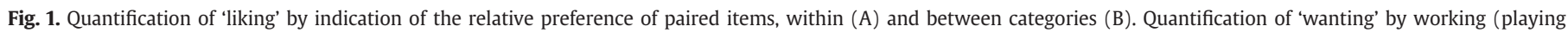
memory games $(C))$ to earn items to choose from (D).

indicate whether they preferred to choose food items from a larger variety, which they would receive as a fixed amount, or whether they preferred to choose the amount of food from a fixed menu. In both cases subjects were asked to assume that the items offered would be acceptable. Most subjects (76\%) preferred food variety to choose from instead of amount of food. Therefore we decided upon primarily magnitude of food variety per category as reinforcer and secondarily meal size represented by the amount of categories worked for.

Software for this computer test was developed using Labview (National Instruments, Austin, USA) excluding express routines, compiled for 13 in. Mac Book and configured to run in Kiosk mode for full control of screen and subject interaction. The software incorporated configurable events and timing tables, allowing the researcher to optimize sequences of events, amount of graphical information and allotted time for choices and instructions. The software logged all events, score and time as well as all user interaction. These data were collected in Excel data sheets. The program used three functions, i.e. a 'liking', memory game and 'wanting' part. These functions where used for each food group in programmed sequence.

Tables generated for 'liking', i.e. 66 selections for 12 items in a category, were evenly randomized in sequence as well as for left-right position on screen. Each item could achieve an initial score of $0-11$, i.e. the count of times the item was preferred over other items in the group. The final score of each item, if the selection was true, was defined as the sum of the initial scores of non-preferred item, times 10 and offset by five, i.e. final score $=$ sum (if selection true (initial score of non-preferred item $\times 10+5$ ) else 0 ). The range of the score was between 0 and 605 per item in each category and incorporated weight of preference. The final score was then used to re-rank items in 12 positions for cross category comparison with equal ranking items from the six categories (score range per item 0-125).

Graphical information in the five by five item display of the memory game was also evenly randomized and included a re-seeding routine for preventing side by side or diagonal combinations. The software standard forced a blank image in the middle position as the selected board size was an uneven number. Information gathered for the memory game included counts of pairs found with and without prior viewing as well as other details regarding timing, position and counts of unsuccessful pairs.

\subsection{Test meal}

The test meal consisted of either chocolate mousse or cottage cheese (both $0.6 \mathrm{MJ}$ per $100 \mathrm{~g}$; energy \% protein/carbohydrate/fat: $21 / 29 / 50)$ and a glass of water $(250 \mathrm{~mL})$. The amount of chocolate mousse or cottage cheese given to the subjects corresponded to $10 \%$ of their daily energy requirements (DER). For each subject the DER were calculated by multiplying the basal metabolic rate (BMR) by the 
appropriate physical activity factor (1.5-1.8, derived from the screening questionnaire, [15]). The BMR (kcal/day) was calculated according to the equation of Harris-Benedict [16]. The order of presentation of the test meal was randomized across the subjects to prevent any order effects. On average subjects received $1.2 \mathrm{MJ}$ of chocolate mousse or cottage cheese. The chosen meal size of $10 \%$ of DER was based on a study by Diepvens et al. showing that a breakfast of $1 \mathrm{MJ}$, or $10 \%$ of subject specific DER, with a similar macronutrient composition (energy \% protein/carbohydrate/fat: 25/33/42) induced significant changes in hunger and satiety [17].

Chocolate mousse, a dessert-specific food item and cottage cheese, a dessert non-specific, neutral food item, were both part of the dessert category. These two items were chosen as test meal, as it was expected that they would differ in rewarding value, chocolate mousse being more rewarding than cottage cheese. As appeared during screening, chocolate mousse was mostly described as a delicious food item and cottage cheese as a healthy food item. Consequently consumption of the items was expected to exert different effects on the rewarding value, in terms of 'liking' and 'wanting', of the consumed food item itself, the dessert category and possible other categories.

\subsection{Validity}

The validity of the computer test was determined by assessing reproducibility and sensitivity. To measure the reproducibility of the 'liking' and 'wanting' part of the computer test and of the absolute 'liking' of all the used items determined by VAS, the percentage reproducibility was calculated, based on two repeated measures from each individual. For the 'liking' and 'wanting' part of the computer test the measures in the fasted state of test day 1 and test day 2 were compared. The percentage reproducibility was calculated as the proportion of concordance between the repeated measurements, expressed as percent. A reproducibility of $60 \%$ was accepted as sufficient. The sensitivity of the computer test was evaluated by the ability of the test to detect differences in rewarding value of the used items between pre- to postconsumption of chocolate mousse and cottage cheese.

\subsection{Statistics}

Data were analyzed using StatView 5.0 (SAS Institute Inc., Cary, NC, USA). Differences between pre- to post-meal were determined using paired Student's $t$-tests. Differences over time and between conditions (chocolate mousse and cottage cheese) were determined using twofactor analysis of variance (ANOVA) with repeated measures. The Wilcoxon signed-rank test was used to detect differences in the ranking of 'liking' of items within each category between pre- to post-meal. To analyze which independent variables (hunger, thirst, fullness, satiety, desire to eat, 'liking', creaminess, fullness) predicted the dependent variables 'wanting' for chocolate mousse and 'wanting' for cottage cheese, simple linear regression models were used. To compare the mean absolute and relative 'liking' scores of the food items of all subjects, measured by VAS and the 'liking' part of the computer test, respectively, a simple linear regression model was used. Both measuring scales were normalized to $100 \%$ first.

All tests were two-sided and differences were considered significant at $p<0.05$. Values are expressed as mean \pm standard error of the mean (SEM).

\section{Results}

\subsection{Reproducibility}

Based on the computer test measurements for all subjects in a fasted state on test day 1 and test day 2 , the mean percentage of reproducibility of all subjects was $62.3 \pm 0.6 \%$ for the 'liking' part and $73.3 \pm 2.6 \%$ for the 'wanting' part. For the absolute 'liking' of all the used items determined by VAS, the percentage reproducibility was $76.2 \pm 1.2 \%$.

A positive relationship was observed between mean absolute and relative 'liking' scores of the items of all subjects, measured by VAS and the 'liking' part of the computer test, respectively $\left(R^{2}=0.63\right.$, $p<0.001$ ). Fig. 2 depicts a scatter plot of the relative 'liking' scores as a function of the absolute 'liking' scores distributed about the line of identity. The scatter plot lies beneath the line of identity, suggesting although the scores are highly correlated, the absolute 'liking' scores are continuously higher than the relative 'liking' scores.

\subsection{Appetite profile}

High ratings for hunger and desire to eat and low ratings for fullness and satiety confirmed that subjects were in a fasted state at the start of both test sessions (Table 1). Both test meals, chocolate mousse and cottage cheese served with a glass of water, induced a decrease in hunger, thirst and desire to eat $(p<0.001)$ and an increase in fullness and satiety $(p<0.001$, Table 1$)$. These results confirmed that subjects were in a satiated state when they fulfilled the second computer test.

There was a significant time by condition (pre-/post-meal $\times$ chocolate mousse/cottage cheese) interaction for hunger $(p<0.01)$, desire to eat $(p<0.01)$, fullness $(p<0.01)$, satiety $(p<0.001)$ and 'wanting' $(p=0.02$, Table 1$)$. The difference in hunger, desire to eat, fullness and satiety pre- to post-consumption was larger in the chocolate mousse condition than in the cottage cheese condition $(p<0.01)$. Subjects were less hungry, had a lower desire to eat and were more full and satiated after the consumption of chocolate mousse than after the consumption of cottage cheese $(p<0.001)$.

Chocolate mousse was liked more than cottage cheese, before as well as after the consumption of both food items $(p<0.001$, Table 1$)$. The consumption of chocolate mousse induced a decrease in 'liking' and 'wanting' for chocolate mousse $(p<0.001$, Table 1$)$. The consumption of cottage cheese induced a decrease in 'liking' and 'wanting' for cottage cheese $(p<0.001$, Table 1$)$. The difference in 'wanting' for chocolate mousse or cottage cheese pre- to post-consumption was larger in the chocolate mousse condition than in the cottage cheese condition $(p<0.01$, Table 1$)$. Chocolate mousse was perceived as more full of taste than cottage cheese, before and after the consumption of both food items $(p<0.001$, Table 1$)$.

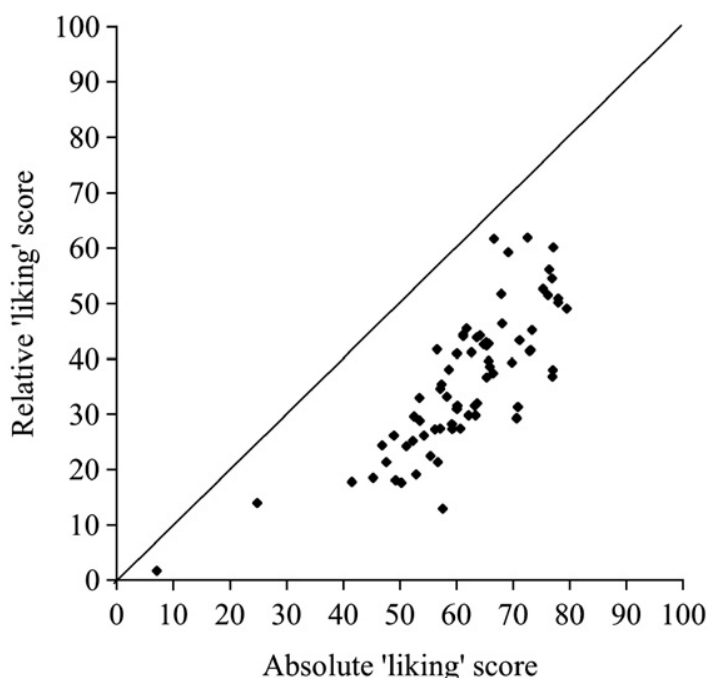

Fig. 2. Scatter plot of the mean relative 'liking' scores as a function of the absolute 'liking' scores of the 72 items, distributed about the line of identity $(x=y)$. The relative 'liking' scores of the 72 items were obtained by means of the 'liking' part of the computer test and the absolute 'liking' scores by means of visual analogue scales (mm). Each data point of the scatter plot represents an individual item. 
Table 1

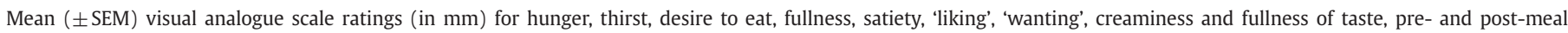
(chocolate mousse, CM; cottage cheese, $\mathrm{CC}$ ).

\begin{tabular}{|c|c|c|c|c|c|c|c|}
\hline & \multicolumn{3}{|l|}{$\mathrm{CM}$} & \multicolumn{4}{|l|}{$\mathrm{CC}$} \\
\hline & Pre & Post & $p^{a}$ & Pre & Post & $p^{a}$ & $p^{\mathrm{b}}$ time $\times$ condition \\
\hline Hunger & $57.0 \pm 2.9$ & $11.4 \pm 1.8$ & $<.001$ & $58.6 \pm 2.5$ & $23.9 \pm 2.4$ & $<.001$ & .01 \\
\hline Thirst & $60.5 \pm 2.5$ & $40.7 \pm 3.1$ & $<.001$ & $61.8 \pm 2.0$ & $38.8 \pm 3.1$ & $<.001$ & n.s. \\
\hline Desire to eat & $59.1 \pm 2.8$ & $13.3 \pm 1.9$ & $<.001$ & $62.4 \pm 2.4$ & $28.6 \pm 2.8$ & $<.001$ & $<.01$ \\
\hline Fullness & $20.0 \pm 2.1$ & $80.1 \pm 2.0$ & $<.001$ & $19.1 \pm 2.2$ & $65.7 \pm 2.7$ & $<.001$ & $<.01$ \\
\hline Satiety & $20.3 \pm 1.9$ & $79.0 \pm 2.3$ & $<.001$ & $21.4 \pm 2.2$ & $63.3 \pm 2.7$ & $<.001$ & $<.001$ \\
\hline ‘Liking’ & $67.6 \pm 2.9$ & $57.6 \pm 3.3$ & $<.001$ & $49.4 \pm 2.8$ & $40.4 \pm 3.4$ & $<.001$ & n.s \\
\hline 'Wanting' & $47.6 \pm 3.3$ & $9.0 \pm 1.8$ & $<.001$ & $42.6 \pm 3.0$ & $14.1 \pm 2.0$ & $<.001$ & .02 \\
\hline Creaminess & $70.2 \pm 2.7$ & $69.0 \pm 3.3$ & n.s. & $65.2 \pm 3.0$ & $69.9 \pm 2.9$ & n.s. & n.s. \\
\hline Fullness of taste & $78.1 \pm 2.3$ & $75.1 \pm 2.8$ & n.s. & $57.3 \pm 3.3$ & $56.7 \pm 3.9$ & n.s. & n.s. \\
\hline
\end{tabular}

n.s. $=$ non-significant

a $p$-value: differences pre- to post-meal ( $t$-test).

b $p$-value: time by condition interaction (pre-/post-meal $\times$ chocolate mousse/cottage cheese; ANOVA).

Simple linear regression models showed a positive relationship between pre-meal 'wanting' for chocolate mousse and pre-meal 'liking' for chocolate mousse $\left(R^{2}=0.5, p<0.001\right)$, as well as hunger $\left(R^{2}=0.2\right.$, $p<0.001)$, desire to eat $\left(R^{2}=0.2, p<0.001\right)$, creaminess $\left(R^{2}=0.2\right.$, $p<0.01)$ and fullness of taste $\left(R^{2}=0.2, p<0.01\right)$. There was a negative relationship between pre-meal 'wanting' for chocolate mousse and premeal satiety $\left(R^{2}=0.1, p=0.02\right)$.

In the cottage cheese condition, simple linear regression models showed a positive relationship between pre-meal 'wanting' for cottage cheese and pre-meal 'liking' for cottage cheese $\left(R^{2}=0.6, p<0.001\right)$, as well as hunger $\left(R^{2}=0.1, p=0.02\right)$, desire to eat $\left(R^{2}=0.1, p<0.01\right)$ and fullness of taste $\left(R^{2}=0.3, p<0.001\right)$.

Post-meal 'wanting' for chocolate mousse was positively related to post-meal 'liking' for chocolate mousse $\left(R^{2}=0.07, p=0.03\right)$, hunger $\left(R^{2}=0.07, p=0.02\right)$, desire to eat $\left(R^{2}=0.2, p<0.001\right)$ and negatively to post-meal fullness $\left(R^{2}=0.1, p<0.01\right)$. Post-meal 'wanting' for cottage cheese was positively related to post-meal 'liking' for cottage cheese $\left(R^{2}=0.3, p<0.001\right)$ and desire to eat $\left(R^{2}=0.1, p<0.01\right)$.

Simple linear regression models showed a positive relationship between the difference in hunger $\left(R^{2}=0.1, p<0.01\right)$ and desire to eat $\left(R^{2}=0.1, p=0.03\right)$ pre- to post-consumption of chocolate mousse as dependent variables and fullness of taste of chocolate mousse pre-meal as independent variable. There was a negative relationship between the difference in fullness pre- to post-consumption of chocolate mousse and fullness of taste of chocolate mousse pre-meal $\left(R^{2}=0.1, p=0.02\right)$. A positive relationship was detected between the difference in hunger $\left(R^{2}=0.1, p=0.02\right)$ and desire to eat $\left(R^{2}=0.1, p=0.04\right)$ pre- to postconsumption of chocolate mousse and 'liking' of chocolate mousse pre- meal. These relationships were not found in the cottage cheese condition.

\subsection{Computer test sensitivity}

Results of the computer test for relative 'liking' between categories are shown in Fig. 3. Pre- to post-consumption of chocolate mousse, a change in the ranking of 'liking' of the six categories was observed, thereby decreasing the dessert category $(p<0.001)$ and increasing the placebo, i.e. the stationery category $(p<0.001)$, and the drinks category $(p<0.01)$. Pre- to post-consumption of cottage cheese, a decrease in the ranking of 'liking' of filling $(p<0.01)$ and an increase in the ranking of 'liking' of stationery $(p<0.001)$ and sweets $(p<0.01)$ was observed. There was a significant influence of the test meal on 'liking' for drinks $(p=0.01)$ and dessert $(p<0.001)$ pre- to post-meal. After consumption of chocolate mousse compared to consumption of cottage cheese, the stationery $(p=0.04)$ and drinks category $(p=0.01)$ had a higher ranking of 'liking', while the dessert category had a lower ranking of 'liking' $(p<0.001)$.

The ranking of 'liking' of the items within each category did not change significantly after consumption of chocolate mousse or cottage cheese $(p>0.1)$.

There was no significant time by condition (pre-/post-meal $\times$ chocolate mousse/cottage cheese) interaction for mean 'wanting' for items from any category $(p=0.2)$ and also not for 'wanting' for items per category $(p \geq 0.06)$. The mean 'wanting' for items from any category decreased after consumption of chocolate mousse $(p<0.01)$ as well as cottage cheese $(p=0.03)$.

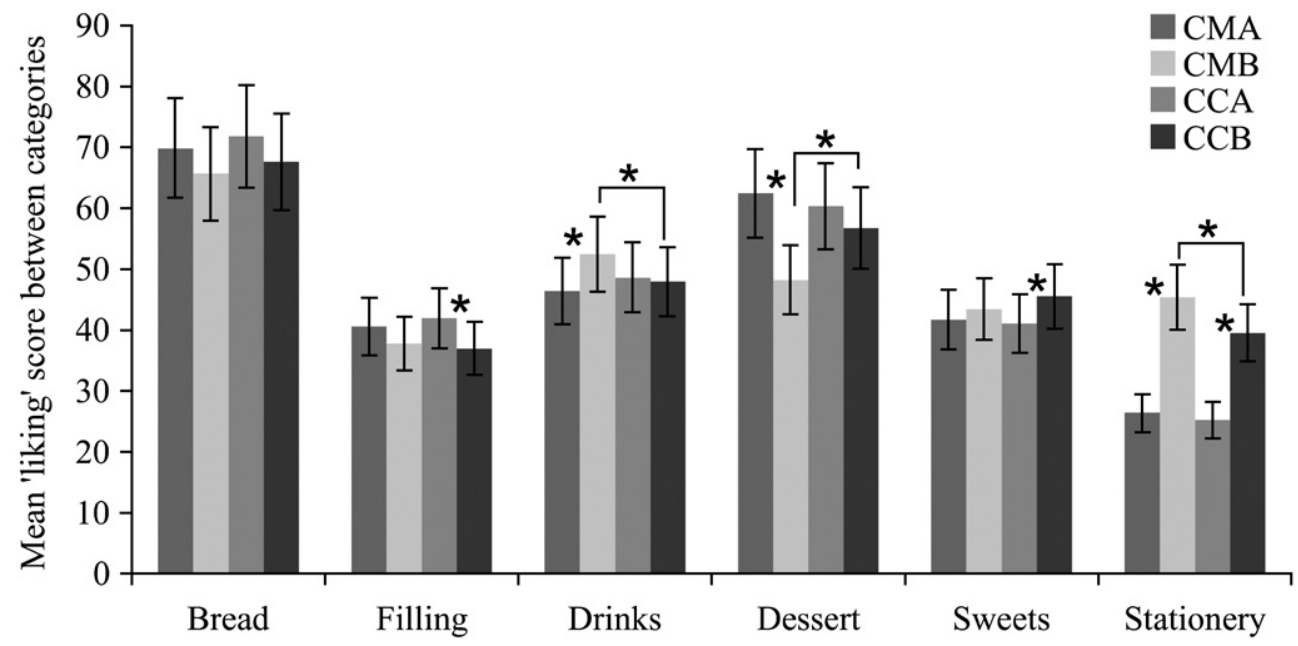

Fig. 3. Relative 'liking' score between categories (mean \pm SEM) pre- and post-consumption of chocolate mousse (CMA, CMB) and cottage cheese (CCA, CCB). ${ }^{*} p<0.05$. 


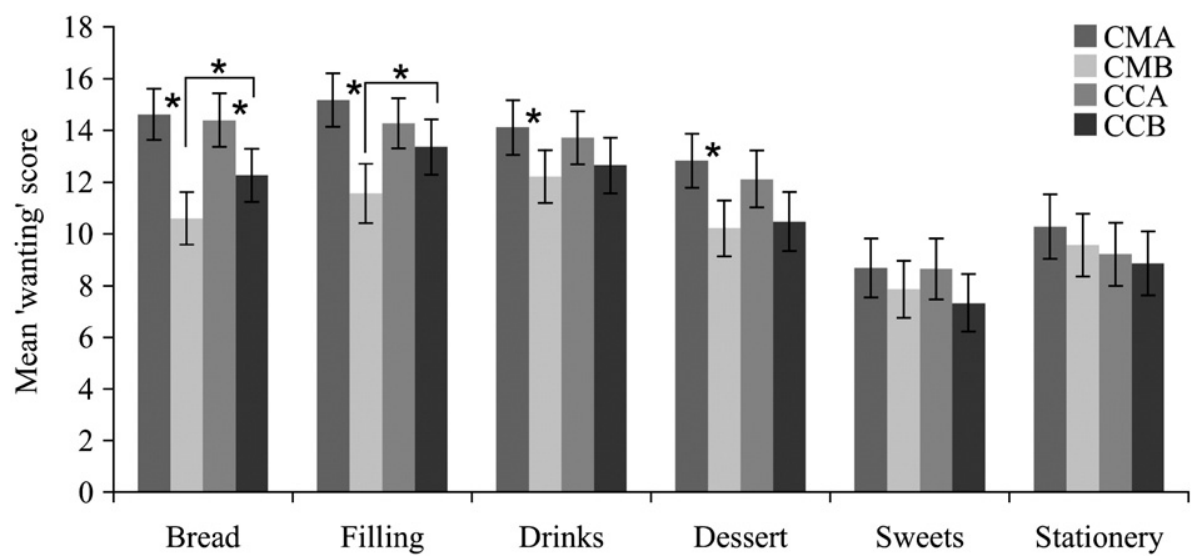

Fig. 4. 'Wanting' score per category (mean \pm SEM) pre- and post-consumption of chocolate mousse (CMA, CMB) and cottage cheese (CCA, CCB). * $p<0.05$.

Results of the computer test for 'wanting' per category are shown in Fig. 4. Consumption of chocolate mousse induced a decrease in 'wanting' for bread $(p<0.001)$, filling $(p<0.001)$, drinks $(p=0.02)$ and dessert $(p<0.01)$. Consumption of cottage cheese induced a decrease in 'wanting' for bread only $(p<0.05)$. After consumption of chocolate mousse 'wanting' for bread $(p=0.04)$ and filling $(p=0.04)$ was lower than after consumption of cottage cheese.

Consumption of chocolate mousse decreased the motivation expressed as workload executed (number of items found in the memory game) for the bread $(p=0.04)$ and filling $(p=0.04)$ category. Consumption of cottage cheese did not decrease the motivation for any category. The motivation for the filling category was lower after consumption of chocolate mousse than after consumption of cottage cheese $(p=0.04)$.

The computer test showed a pre- to post-meal decrease in relative 'liking' for chocolate mousse by $53 \%$, in relative 'liking' for cottage cheese by $17 \%$, in relative 'wanting' for chocolate mousse by $64 \%$ and in relative 'wanting' for cottage cheese by $54 \%$. Subjective VAS showed a pre- to post-meal decrease in 'liking' for chocolate mousse by $15 \%$, in 'liking' for cottage cheese by $18 \%$, in 'wanting' for chocolate mousse by $81 \%$ and in 'wanting' for cottage cheese by $67 \%$. Both relative and absolute methods showed to be sensitive in detecting pre- to postmeal differences.

The sub-study showed that the attractiveness of the photographic stimuli used in the computer test was positively related to the pleasantness of taste of the food items $\left(R^{2}=0.5, p<0.0001\right.$, Fig. 5).

\section{Discussion}

The main objective of this study was to investigate the validity, i.e. reproducibility and sensitivity, of the developed computer test for assessment of the rewarding value of food in terms of 'liking' and 'wanting'. The 'liking' and 'wanting' part of the computer test showed a reproducibility of $62-73 \%$, still allowing room for variation and sensitivity. The computer test was sensitive to detect differences in 'liking' and 'wanting' for the used categories of items between pre- to post-consumption of chocolate mousse and cottage cheese. Thus, the validity of this test was shown to be sufficient.

With respect to the findings using the computer test, consumption of chocolate mousse and cottage cheese induced an increase in relative 'liking', but not in 'wanting', for the non-food alternative, i.e. the stationery category. This increase in 'liking', but not in 'wanting', was also detected for the drinks category in the chocolate mousse condition and for the sweets category in the cottage cheese condition. Consumption of chocolate mousse decreased both 'liking' and 'wanting' for the dessert category. This altogether shows a specific decrease in 'liking' for the food category the eaten food belongs to, relative to placebo, the non-food category. Consumption of chocolate mousse appears to induce a more distinct change in 'liking' and 'wanting' for the different categories than consumption of cottage cheese. These findings may be related to some aspects of the concept of 'sensory specific satiety', which refers to the temporary decrease in pleasantness of a consumed food compared with a non-consumed food [18,19]. In our study, consumption of chocolate mousse, a dessert-specific food item, induced a stronger decrease in 'liking' and 'wanting' for the whole band-width of the dessert category, relative to the other categories, than consumption of cottage cheese.

Previous studies developed and used techniques to assess 'liking' and 'wanting'. Epstein et al. measured subjective estimates of 'liking' using VAS [3]. Objective measures of taste reactivity were obtained by behavioral observation of taste stimuli [3]. The reinforcing value of food, associated with the concept of 'wanting' food, was determined using the concurrent schedules of reinforcement paradigm $[3,13,20]$. Subjects completed a computer-generated concurrent schedules task to earn points that at the end of the task were exchanged for amounts of a preferred snack food or alternate reinforcers such as sedentary activities or money. The results showed that the paradigm was sensitive to the effects of food as a reinforcer [13]. In another study by Epstein et al. on the interaction of food reinforcement and dopamine genotypes on eating, retesting 20 subjects verified the reliability of the test to measure the reinforcing value of food. A test-retest correlation of $80 \%$ was detected [21]. The measurement of 'wanting' in our study

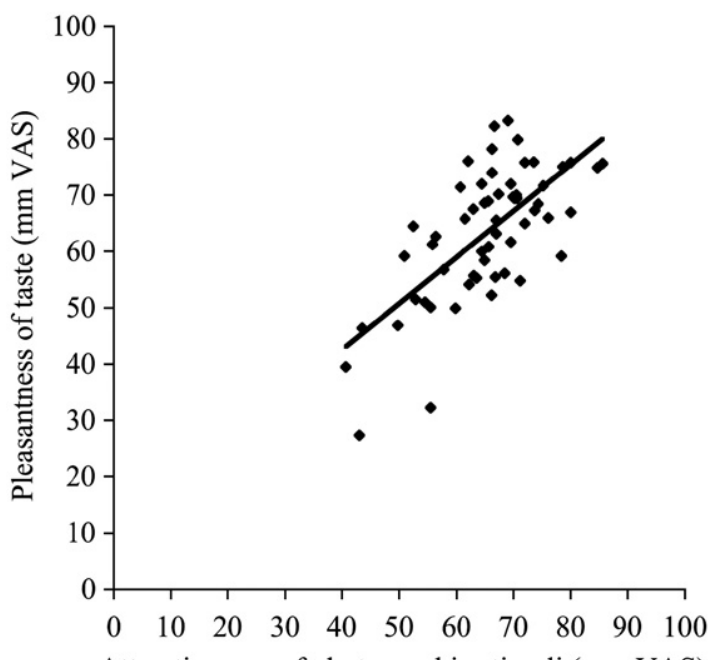

Attractiveness of photographic stimuli (mm VAS)

Fig. 5. Scatter plot of the mean visual analogue scale (VAS) scores (mm) for pleasantness of taste of the food items as a function of the attractiveness of the photographic stimuli of the same food items. 
was comparable to the studies of Epstein et al. in that subjects had to work to gain access to reinforcers as food and stationery as non-food alternative. The difference is that in our study primarily food variety and secondarily amount of food were chosen as reinforcers instead of only amount of food to eat or money to earn. The power of a reinforcer may be influenced by culture: in the Dutch culture the amount of food is a smaller reinforcer than variety to choose from, mainly because in everyday life people in general prefer freedom of choice above hoarding [14]. This was also reflected in our data: $76 \%$ of our subjects preferred food variety instead of amount of food. In the present study subjects only received chocolate mousse or cottage cheese, without choice, yet this standardization was used for validation. In future studies subjects will have to choose from a small to large variety of food items and from the number of categories they have worked for, combining food choice and amount of foods. The chosen food items will then have to be consumed. The Maastricht Medical Ethical Committee does not allow introducing money as part of an experiment, since all subjects should get paid equally for participation in an experiment.

Finlayson et al. developed a computerized tool to measure 'liking' and 'wanting' [2,5,22]. Explicit 'liking' and 'wanting' were measured using VAS combined with the questions "How pleasant would it be to experience a mouthful of this food now?" and "How much do you want some of this food now?" Implicit 'wanting' was measured by means of a forced choice paradigm. Stimuli were presented in pairs and subjects had to respond to according to which food they would most like to eat at that moment. The implicit 'wanting' paradigm was improved by measuring the reaction time of each choice. This provided a quantifiable measure related to the relative 'wanting' for that chosen food item. Food was the only reinforcer used in this paradigm; there were no alternate reinforcers. Whether the validity of this computerized tool was tested, is not completely clear. Finlayson et al. indicate that the forced choice paradigm measures relative behavioral preference and probably contains an element of 'liking'. The incorporation of the reaction time measurement in the studies of Finlayson et al. is an improvement of the paradigm and might give a better indication of the motivation to obtain a desired food. We used the forced choice paradigm for the assessment of relative 'liking' (preference) instead of 'wanting'. Our subjects had to indicate their preference of paired items as a measure of relative 'liking'. In addition, their 'liking' was measured absolutely by means of subjective VAS. A positive relationship was found between the scores of both 'liking' measures, which indicates that outcomes were rather stable within subjects, yet absolute 'liking' scores were continuously higher than relative 'liking' scores. The difference between absolute and relative 'liking' scores is of interest since it indicates the difference between highly liked but still less liked items.

The attractiveness of the visual input used in our computer test was positively related to the pleasantness of taste of the food items. This indicates that the used photographic stimuli are representative for the actual taste of the food items and are cues that can predict 'liking' and possibly 'wanting'.

Chocolate mousse, a dessert-specific food item, was liked more and perceived as more full of taste than cottage cheese, a dessert nonspecific and neutral food item. Chocolate mousse induced a larger decrease in hunger and desire to eat than cottage cheese, although the offered amount of both food items was isoenergetic. These findings can be explained by the higher 'liking' and fullness of taste of chocolate mousse compared with cottage cheese. This is in accordance with previous research showing that palatability prolongs satiation [23].

Subjective estimates of 'liking' and 'wanting' for chocolate mousse and cottage cheese were measured using VAS. In the fasted state, 'liking' for chocolate mousse or cottage cheese was the best predictor for 'wanting' for both food items. In the satiated state, 'wanting' for chocolate mousse was predominantly determined by desire to eat in general, and 'wanting' for cottage cheese was determined by 'liking' for cottage cheese. These results may implicate that food 'wanting' in the satiated state is predominantly determined non-homeostatically by 'liking' or desire to eat: in the absence of hunger, chocolate mousse will only be eaten if there is still a desire to eat, while cottage cheese will only be eaten if it is liked very much.

In summary, the developed computer test for measurement of reward in terms of 'liking' and 'wanting' is valid in that it has a sufficient reproducibility and sensitivity. Consumption of a food item that is highly liked and perceived as highly full of taste induces a more distinct decrease in hunger, desire to eat and 'wanting' of food items in general than consumption of a neutral food item. Moreover, only such a highly liked food item induces a reduction in ranking of its categoryspecific 'liking', relative to other categories.

Thus, the main goal of the current study, which was the validation of the computer test, appears to have been achieved, and as a methodological contribution this technique seems likely to be useful in the future.

\section{Acknowledgements}

We thank our subjects for their participation in this study and Sanne Verhoef for her help with the practical work. The study was designed by MSWP and SGTL. SGTL (supervised by MSWP) carried out the study, collected and analyzed the data and wrote the largest part of the manuscript. PFMS, together with SGTL and LW, developed the computer test for measurement of 'liking' and 'wanting'. MJI carried out the sub-study measuring the attractiveness of the photographic stimuli and the pleasantness of taste of the food items. FR and JMB reviewed the manuscript.

\section{Appendix A}

Table A1

Description of the 72 items divided in six categories used in this study.

\begin{tabular}{|c|c|c|c|c|c|}
\hline Bread & Filling & Drinks & Dessert & Sweets & Stationery \\
\hline Baguette & Apricot jam & Apple juice & Apple & Cigarette & Blocknote \\
\hline Brown bread & Brie cheese & Buttermilk & Banana & $\begin{array}{l}\text { Doritos } \\
\text { (nacho cheese) }\end{array}$ & Marker \\
\hline $\begin{array}{l}\text { Brown hard } \\
\text { roll }\end{array}$ & Chocolate paste & $\begin{array}{l}\text { Carbonated } \\
\text { water }\end{array}$ & $\begin{array}{l}\text { Butter } \\
\text { cookie }\end{array}$ & $\begin{array}{l}\text { Lay's natural } \\
\text { chips }\end{array}$ & Paper \\
\hline $\begin{array}{l}\text { Brown soft } \\
\text { bread }\end{array}$ & $\begin{array}{l}\text { Chocolate } \\
\text { sprinkles }\end{array}$ & $\begin{array}{l}\text { Chocolate } \\
\text { milk }\end{array}$ & Cake & $\begin{array}{l}\text { Lay's paprika } \\
\text { chips }\end{array}$ & Pen \\
\hline Cracker & Egg salad & Coca cola & $\begin{array}{l}\text { Chocolate } \\
\text { custard }\end{array}$ & Liquorish & Pencil \\
\hline Croissant & Forest fruit jam & Fanta & $\begin{array}{l}\text { Chocolate } \\
\text { mousse }\end{array}$ & Milk chocolate & $\begin{array}{l}\text { Pencil } \\
\text { eraser }\end{array}$ \\
\hline Currant bread & Fruit sprinkles & $\begin{array}{l}\text { Fristi (forest } \\
\text { fruit drink } \\
\text { yoghurt) }\end{array}$ & $\begin{array}{l}\text { Cottage } \\
\text { cheese }\end{array}$ & $\begin{array}{l}\text { Napoleon sour } \\
\text { bon bons }\end{array}$ & $\begin{array}{l}\text { Pritt } \\
\text { correction }\end{array}$ \\
\hline Pumpernickel & Gouda cheese & Milk & $\begin{array}{l}\text { Forest } \\
\text { fruit } \\
\text { yoghurt }\end{array}$ & Peanuts & Pritt stick \\
\hline White bread & Ham & Orange juice & $\begin{array}{l}\text { Liege } \\
\text { waffle }\end{array}$ & $\begin{array}{l}\text { TUC } \\
\text { (original) } \\
\text { biscuits }\end{array}$ & Ruler \\
\hline $\begin{array}{l}\text { White hard } \\
\text { roll }\end{array}$ & Peanut butter & Plain water & $\begin{array}{l}\text { Marzipan } \\
\text { cake }\end{array}$ & Twix & Scissors \\
\hline $\begin{array}{l}\text { White soft } \\
\text { roll }\end{array}$ & Salami & Schweppes & Orange & $\begin{array}{l}\text { White } \\
\text { chocolate }\end{array}$ & Sharpen \\
\hline $\begin{array}{l}\text { Whole wheat } \\
\text { roll }\end{array}$ & Sandwichspread & $\begin{array}{l}\text { White wine } \\
\text { (alcohol free) }\end{array}$ & $\begin{array}{l}\text { Vanilla } \\
\text { custard }\end{array}$ & Wine gums & Tape \\
\hline
\end{tabular}

\section{References}

[1] Berthoud HR. Neural control of appetite: cross-talk between homeostatic and nonhomeostatic systems. Appetite Dec 2004;43(3):315-7.

[2] Finlayson G, King N, Blundell JE. Liking vs. wanting food: importance for human appetite control and weight regulation. Neurosci Biobehav Rev Mar 272007.

[3] Epstein LH, Truesdale R, Wojcik A, Paluch RA, Raynor HA. Effects of deprivation on hedonics and reinforcing value of food. Physiol Behav Feb 2003;78(2):221-7. 
[4] Berridge KC. Food reward: brain substrates of wanting and liking. Neurosci Biobehav Rev 1996;20(1):1-25

[5] Finlayson G, King N, Blundell JE. Is it possible to dissociate 'liking' and 'wanting' for foods in humans? A novel experimental procedure. Physiol Behav Jan 30 2007;90 (1):36-42.

[6] Mela DJ. Eating for pleasure or just wanting to eat? Reconsidering sensory hedonic responses as a driver of obesity. Appetite Jul 2006;47(1):10-7.

[7] Berridge KC. Motivation concepts in behavioral neuroscience. Physiol Behav Apr 2004;81(2):179-209.

[8] Stunkard AJ, Messick S. The three-factor eating questionnaire to measure dietary restraint, disinhibition and hunger. J Psychosom Res 1985;29(1):71-83.

[9] Robinson TE, Berridge KC. Incentive-sensitization and addiction. Addiction 2001 Jan;96(1):103-14.

[10] Berridge KC, Robinson TE. The mind of an addicted brain: neural sensitization of wanting versus liking. Curr Dir Psychol Sci 1995;4(3):71-6.

[11] Epstein LH, Wright SM, Paluch RA, Leddy J, Hawk Jr LW, Jaroni JL, et al. Food hedonics and reinforcement as determinants of laboratory food intake in smokers. Physiol Behav May 2004;81(3):511-7.

[12] Steiner JE. Human facial expressions in response to taste and smell stimulation. Adv Child Dev Behav 1979;13:257-95.

[13] Lappalainen R, Epstein LH. A behavioral economics analysis of food choice in humans Appetite 1990 Apr;14(2):81-93.

[14] Hofstede G. Culture's consequences, comparing values, behaviors, institutions, and organizations across nations. Thousand Oaks CA: Sage Publications; 2001.
[15] McArdle WD, Katch FI, Katch VL. Exercise physiology. 4th ed. Baltimore: Williams and Watkins; 1996.

[16] Harris JA, Benedict FG. A biometric study of human basal metabolism. Proc Natl Acad Sci USA Dec 1918;4(12):370-3.

[17] Diepvens K, Haberer D, Westerterp-Plantenga M. Different proteins and biopeptides differently affect satiety and anorexigenic/orexigenic hormones in healthy humans. Int J Obes (Lond) Mar 2008;32(3):510-8.

[18] Rolls BJ. Sensory-specific satiety. Nutr Rev Mar 1986;44(3):93-101.

[19] Sorensen LB, Moller P, Flint A, Martens M, Raben A. Effect of sensory perception of foods on appetite and food intake: a review of studies on humans. Int J Obes Relat Metab Disord Oct 2003;27(10):1152-66.

[20] Saelens BE, Epstein LH. Reinforcing value of food in obese and non-obese women. Appetite Aug 1996;27(1):41-50.

[21] Epstein LH, Temple JL, Neaderhiser BJ, Salis RJ, Erbe RW, Leddy JJ. Food reinforcement, the dopamine D2 receptor genotype, and energy intake in obese and nonobese humans. Behav Neurosci Oct 2007;121(5):877-86.

[22] Finlayson G, King N, Blundell J. The role of implicit wanting in relation to explicit liking and wanting for food: Implications for appetite control. Appetite Jan 2008;50 (1):120-7.

[23] De Graaf C, De Jong LS, Lambers AC. Palatability affects satiation but not satiety. Physiol Behav Jun 1999;66(4):681-8. 